\title{
Aplikasi Metode Untuk Pemisahan Aliran Dasar Berbasis Filter Digital: Studi di Wilayah DAS Brantas
}

\author{
Application of recursive digital filter (RDF) methods for baseflow separation: study at Brantas \\ watershed
}

Indarto Indarto $^{\mathrm{a}}$, Elida Novita ${ }^{\mathrm{a}}$, Sri Wahyuningsih ${ }^{\mathrm{a}}$, Nur Defitri Herlinda ${ }^{\mathrm{a}}$, Entin Hidayah ${ }^{\mathrm{b}}$,

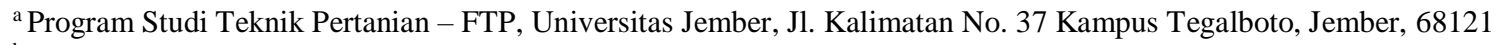

${ }^{\mathrm{b}}$ Program Studi Teknik Sipil - FT, Universitas Jember, Jl. Kalimatan No. 37 Kampus Tegalboto, Jember, 68121

\section{Article Info:}

Received: 05 - 03 - 2018

Accepted: 06 - 05 - 2018

Keywords:

Baseflow, separation, digital filter, Brantas.

Corresponding Author: Indarto

Program Studi Teknik Pertanian FTP UNEJ. J1. Kalimantan no. 37 Kampus Tegalboto Jember 68121

Tel. +62-331 3217852, 321785

Email: indarto.ftp@unej.ac.id

\begin{abstract}
Baseflow is an important component affecting the availability of water in the river during the dry season. Availability of water in the dry season is useful for water resources management. This research aims to test and to compare six recursive digital filters (RDF) methods for calculating baseflow and baseflow index. This research was conducted in Brantas Watershed. Two outlets (sub-watersheds) located at Kertosono and Ploso were used. Daily discharge from 1996 to 2015 of the two outlets above was used as main input for this study. While rainfall data were used to determine the calibration period. The sequence procedures of this research, consist of: (1) inventory of daily discharge and rainfall data, (2) data processing, (3) calibration, (4) validation, and (5) evaluation of models' performances. Six (6) methods of baseflow separation based on recursive digital filters were evaluated. The calibration process was carried out for periods 1996 to 2005. The periods from July to September was assumed to be the peak of the dry season and then selected for calibration process. The parameter values were calibrated using the data from dry season for each year. Furthermore, the average value of parameters obtained from calibration period then used to separate baseflow in validation process (periods 2006 to 2015). The result of separation both in calibration and validation are then evaluated using root mean square error (RMSE), coefficient of determination $\left(R^{2}\right)$ and FDC. This research shows that the Lyne-Hollick and EWMA filters perform better than other methods. In Brantas Kertosono sub-watershed, the optimal parameter value for Lyne Hollick algoritmh $\left(\alpha_{l y}\right)=0.995$ dan for EWMA filter $\left(\alpha_{e w}\right)=0.003$ and in Brantas Ploso sub-watershed $\left(\alpha_{l y}\right)=0.99$ dan $\left(\alpha_{\text {ew }}\right)=0.003$.
\end{abstract}

How to cite (CSE Style $8^{\text {th }}$ Edition):

Indarto I, Novita E, Wahyuningsih S, Herlinda ND, Hidayah E. 2019. Aplikasi metode untuk pemisahan aliran dasar berbasis filter digital: Studi di wilayah DAS Brantas. JPSL 9(3): 626-640. http://dx.doi.org/10.29244/jps1.9.3.626-640.

\section{PENDAHULUAN}

\section{Latar Belakang}

Ketersediaan air di wilayah DAS Brantas berperan penting dalam kegiatan pertanian dan kegiatan lainnya di daerah tersebut. Pada musim kemarau intensitas hujan berkurang sehingga ketersediaan air di sungai sangat terbatas. Aliran dasar merupakan komponen penting yang mempengaruhi ketersediaan air di sungai pada musim kemarau. Perkiraan besarnya aliran dasar (baseflow) yang tersedia pada saat musim kemarau, sangat 
dibutuhkan untuk manajemen sumberdaya air di dalam DAS tersebut. Informasi tentang ketersediaan aliran dasar diperlukan untuk membuat suatu perencanaan alokasi (pemanfaatan) air dalam rangka pengelolaan sumberdaya air. Selanjutnya, hasil pemisahan aliran dasar dapat bermanfaat untuk menghitung ketersediaan air pada saat musim kemarau (atau periode debit kecil atau periode kering). Manfaat lain dari perhitungan aliran dasar adalah untuk konservasi lingkungan perairan di Sungai. Selain manusia, banyak spesies hewan dan tumbuhan yang hidupnya tergantung pada ketersediaan aliran di sungai. Dengan mengetahui ketersediaan aliran dasar, kita dapat memperkirakan apakah lingkungan di sungai masih dapat mendukung dan menjamin keberlangsungan kehidupan biota dan jenis ikan yang ada di Sungai, terutama pada saat periode debit kecil. Pada saat musim kemarau, relatif tidak ada hujan yang jatuh, tetapi pada kebanyakan sungai di Jawa timur masih ada debit air yang mengalir. Aliran air sungai ini berasal dari komponen aliran yang disebut dengan baseflow. Aliran ini berasal dari air hujan yang terinfiltrasi dan masuk ke dalam tanah menjadi cadangan air tanah dan akan bergabung dengan aliran sungai (Indarto 2010).

Pada prinsipnya, aliran dasar (base flow) dan aliran cepat (quick flow) tidak dapat dibedakan dari data debit yang terukur di sungai, karena debit terukur di sungai merupakan gabungan dari kedua komponen tersebut. Metode pemisahan aliran dasar umumnya membagi aliran menjadi aliran cepat dan aliran dasar mengguna-kan pemisahan otomatis berbasis waktu. Pemisahan ke dua komponen dapat dilakukan menggunakan metode atau algoritma. Terdapat banyak metode yang digunakan untuk pemisahan aliran dasar. Literatur terkait dengan analisis aliran dasar, antara lain telah ditulis oleh: Boughton (1993), Nathan dan McMahon (1990ab), Tallaksen (1995), Chapman dan Maxwell (1996), Smakhtin (2001ab), Brodie dan Hostetler (2007), Furey (2003), Tularam dan Ilahee (2008), Eckhardt (2005, 2008), dan Gonzales etal.,(2009) menunjukkan beberapa perkembangan pema-haman dan analisis terhadap aliran dasar.

Tabel 1 memuat jenis metode RDF yang digunakan untuk pemisahan aliran dasar pada penelitian ini. Tabel 1 diadaptasi dari (Gregor 2010; Indarto et al. 2017).

Tabel 1 Recursive Digital Filter (RDF).

\begin{tabular}{cc}
\hline Nama & Persamaan \\
\hline One parameter algorithm (Chapman dan Maxwell, 1996) & $q_{b(i)}=\frac{k}{2-k} q_{b(i-1)}+\frac{1-k}{2-k} q_{(i)}$ \\
\hline Two parameter algorithm (Boughton, 1993) & $q_{b(i)}=\frac{k}{1+C} q_{b(i-1)}+\frac{C}{1+C} q_{(i)}$ \\
\hline IHACRES three parameter algorithm (Jakeman dan Hornberger, & $q_{b(i)}=\frac{k}{1+C} q_{b(i-1)}+\frac{C}{1+C}\left(q_{(i)}+\left(\alpha_{q} q_{(i-1)}\right)\right.$ \\
\hline 1993) & $q_{f(i)}=\alpha q_{f(i-1)}+\left(q_{(i)}-q_{(i-1)}\right) \frac{1+\alpha}{2}$ \\
\hline Lyne \& Holick algorithm (Lyne dan Hollick, 1979) & $q_{f(i)}=\frac{3 \alpha-1}{3-\alpha} q_{f(i-1)}+\frac{2}{3-\alpha}\left(q_{(i)}-\alpha q_{(i-1)}\right)$ \\
\hline Chapman algorithm (Chapman, 1991) & $q_{b(i)}=q_{(i)}+(1+\alpha) q_{b(i-1)}$ \\
\hline
\end{tabular}

\section{Keterangan:}

$\mathrm{q}_{\mathrm{b}(\mathrm{i})} \quad$ : nilai baseflow pada hari ke-i

$\mathrm{q}_{(\mathrm{i})} \quad$ : nilai debit pada hari ke-i

$\mathrm{q}_{\mathrm{f}(\mathrm{i})} \quad$ : merupakan nilai quickflow pada hari ke-i

$\mathrm{q}_{(\mathrm{i}-1)}$ : merupakan debit pada hari sebelumnya

$\mathrm{q}_{\mathrm{b}(\mathrm{i}-1)}$ : nilai baseflow pada hari sebelumnya

$\mathrm{q}_{\mathrm{f}(\mathrm{i})} \quad$ : merupakan nilai quickflow pada hari ke-i

$\mathrm{k} \quad$ : merupakan parameter filter berdasarkan konstanta resesi

$\alpha, \alpha_{\mathrm{q}}:$ merupakan parameter filter

C : merupakan parameter untuk memisahkan aliran dasar.

DAS merupakan lingkungan spesifik dengan berbagai permasalahan komplek di dalamnya. Pemodelan proses hidrologi dan interaksi antara manusia dan lingkungan DAS tetap menjadi main stream penelitian dalam rangka penyelesaian berbagai permasalahan keseharian umat manusia. Penelitian dalam konteks DAS dapat 
berupa pemodelan proses hidrologi misalnya Zumaa et al. (2017). Perhitungan dan prediksi kekeringan (Purnamasaria et al. 2017). Pemodelan kualitas air di dalam DAS (Yetti et al. 2017) dan penelitian berbagai aspek lain terkait dengan proses hidrologi misalnya, banjir, kekeringan, kualitas air, dan neraca air.

Penelitian ini bertujuan untuk mengkalibrasi nilai parameter, membandingkan kinerja ke 6 metode pemisahan aliran berbasis filter digital (RDF). Penelitian dilakukan pada DAS Brantas dengan lokasi AWLR (outlet) di Kertosono dan di Ploso. Kedua stasiun pengukuran debit tersebut ada di wilayah UPT PSDA di Kediri. Penelitian ini merupakan lanjutan dari penelitian yang telah dilakukan sebelumnya oleh Ratnasari, (2015), Puspitasari (2015); Priyanto (2015); Indarto et al. (2015), Indarto et al. (2016); Indarto et al. (2017). Penelitian sebelumnya menerapkan metode pemisahan aliran dasar pada DAS kecil yang ada di Jawa Timur, dengan luas per DAS $<1000 \mathrm{~km}^{2}$. Penelitian ini berbeda dengan penelitian sebelumnya, karena luas DAS yang digunakan pada penelitian mencapai lebih dari $6000 \mathrm{~km}^{2}$. Data debit yang digunakan juga lebih panjang (20 tahun). Semakin panjang data rekaman proses kalibrasi dan validasi menjadi lebih stabil.

\section{METODE}

\section{Lokasi dan Waktu Penelitian}

Lokasi pengamatan ini dilakukan di dua sub-DAS Brantas yang ada di wilayah UPT PSDA Kediri, yaitu: sub-DAS Brantas Ploso dan sub-DAS Brantas Kertosono (Gambar 1). Pengolahan dan analisis data dilakukan di Laboratorium Teknik Pengendalian dan Konservasi Lingkungan (TPKL), PS Teknik Pertanian, FTP, Universitas Jember. Penelitian dilakukan dari Januari sampai Desember 2017.

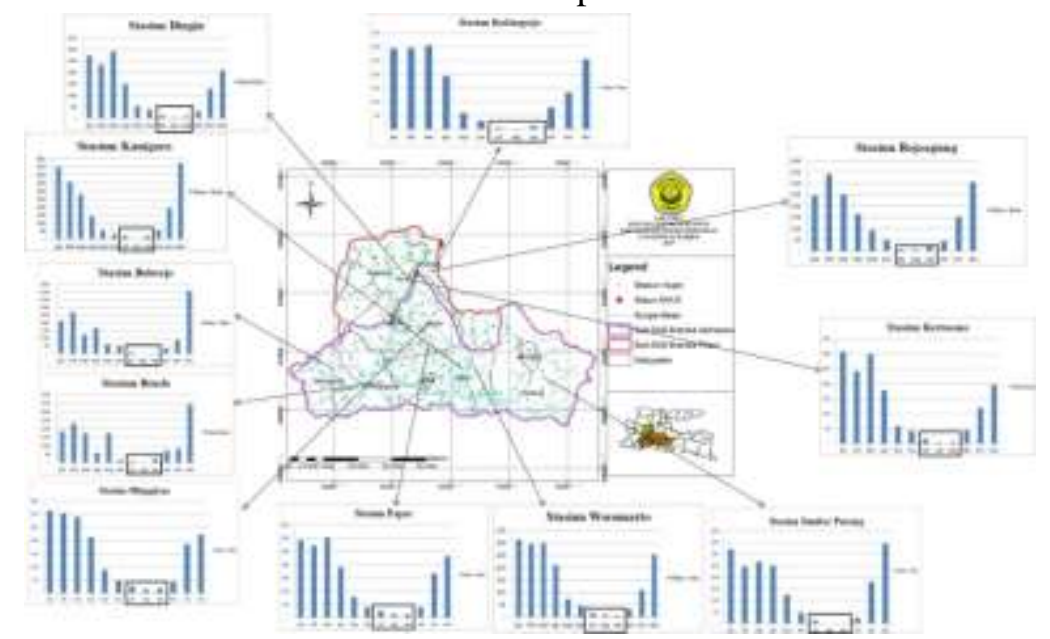

Gambar 1 Lokasi penelitian dan histogram distribusi hujan bulanan pada 11 stasiun hujan.

\section{Metode Pengumpulan Data}

Data hidro-meteorologi harian (debit dan hujan) diperoleh dari kantor UPT PSDA di Kediri, melalui beberapa skema kerjasama (magang, skripsi, penelitian) dan direkap ulang di lab. TPKL-TEP FTP-UNEJ. Data debit diperoleh dari dua lokasi pengukuran debit (AWLR) yaitu: di sub-das Brantas Ploso dan di Brantas Kertosono (Tabel 2). Periode rekaman data debit harian dari 01 Januari 1996 sampai dengan 31 Desember 2015 (20 tahun) digunakan untuk analisis. Data debit selanjutnya diformat ke HydroOffice (Gregor 2012).

Tabel 2 Lokasi sumber data debit.

\begin{tabular}{cccc}
\hline Nama Stasiun & $\begin{array}{c}\text { Koord_X } \\
\left({ }^{\circ} \mathrm{BT}\right)\end{array}$ & $\begin{array}{c}\text { Koord_Y } \\
\left({ }^{\circ} \text { LS }\right)\end{array}$ & Periode (th) \\
\hline Brantas Ploso & $07^{\circ} 27^{\prime} 30^{\prime \prime}$ & $112^{\circ} 13^{\prime} 38^{\prime \prime}$ & 20 \\
Brantas Kertosono & $07^{\circ} 20^{\prime} 50^{\prime \prime}$ & $112^{\circ} 24^{\prime} 51^{\prime \prime}$ & 20 \\
\hline
\end{tabular}


Selanjutnya, analisa statistik ringkasan dan distribusi data debit dilakukan dan menghasilkan nilai indikator statistik (Tabel 3).

Tabel 3 Statisitik debit ( $\mathrm{m}^{3} /$ detik).

\begin{tabular}{ccc}
\hline Debit & Ploso & Kertosono \\
\hline Maximum & 1289.81 & 5063.98 \\
\hline Mean & 204.02 & 319.96 \\
\hline Minimum & 1.99 & 0.73 \\
\hline Median & 154.35 & 216.04 \\
\hline StDev & 173.01 & 410.26 \\
\hline Skewness & 1.32 & 1.48 \\
\hline Variance & 0.85 & 1.28 \\
\hline P10 & 37.80 & 23.84 \\
\hline P20 & 56.20 & 44.21 \\
\hline P25 & 66.37 & 58.51 \\
\hline P30 & 78.92 & 81.66 \\
\hline P33 & 88.22 & 93.76 \\
\hline P50 & 154.35 & 216.04 \\
\hline P66 & 234.00 & 308.04 \\
\hline P70 & 261.00 & 343.80 \\
\hline P75 & 296.09 & 397.15 \\
\hline P80 & 334.87 & 468.82 \\
\hline P90 & 448.73 & 754.33 \\
\hline P100 & 1289.81 & 563.98 \\
\hline V_Lane & 0.44 & 0.60 \\
\hline S_log & 0.44 & 0.60 \\
\hline Slope FDC & 2.96 & 3.60 \\
\hline & &
\end{tabular}

Variabel indikator debit (max, mean, median, StDev, Skewness, variance, P10 sd P100, V_lane, S_log dan Slope FDC) dihitung selama periode 1996 sd 2005 menggunakan perangkat lunak RAP (River Analisys Package) (Marsh 2004), (Marsh et al. 2005), dan HydrOffice (Gregor 2012). Selanjutnya, visualisasi hasil dilakukan menggunakan Excel/OO-calc. Nilai percentile P5, P10, P15, P20, ...., P85, P95, dan P100 dari rekaman data debit yang ada selanjutnya digunakan untuk membuat Kurva Durasi Aliran (KDA) atau flow duration curve (FDC) (Indarto 2016).

Gambar (2) menampilkan kurva durasi aliran (KDA) untuk ke dua sub-DAS. Grafik KDA dapat meringkaskan karakteristik debit pada ke dua sub-DAS sepanjang 1996 sd 2015. Nilai percentile kecil P0 sd P70 menunjukkan domain debit besar sampai sedang. Pada grafik terlihat bahwa semakin besar debit, maka frekuensi kejadian semakin jarang sehingga nilai percentile kecil.

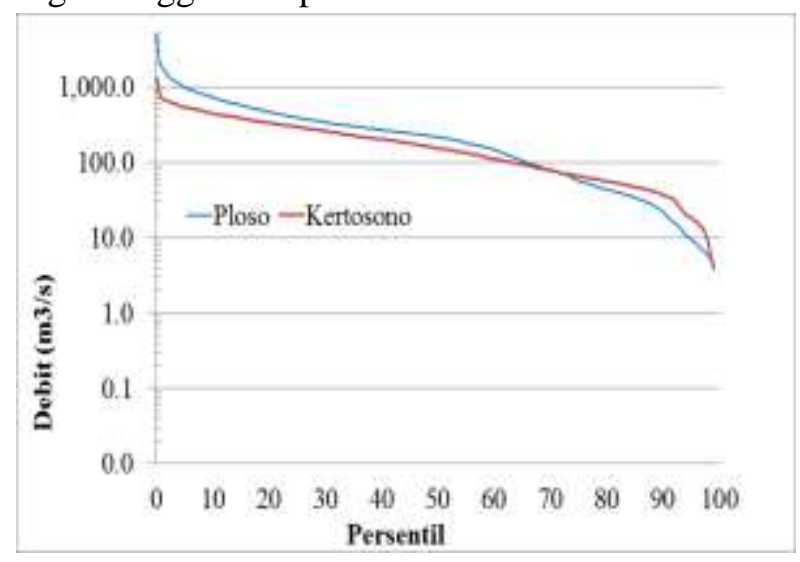

Gambar 2 Kurva Durasi Aliran Pada ke dua sub-DAS. 
Tabel 4 Lokasi sumber data hujan.

\begin{tabular}{ccccc}
\hline \multirow{2}{*}{ No } & Nama Stasiun Hujan & \multicolumn{3}{c}{ Periode Rekaman Data(th) } \\
\cline { 3 - 4 } & Dingin & 1994 & Akhir & Panjang \\
\hline 1 & Kertosono & 1994 & 2015 & 22 \\
\hline 2 & Prayungan & 2003 & 2015 & 22 \\
\hline 3 & Kedungrejo & 1996 & 2015 & 13 \\
\hline 4 & Rejoagung & 2007 & 2015 & 9 \\
\hline 5 & Perak & 1990 & 2015 & 26 \\
\hline 6 & Woromarto & 1990 & 2015 & 26 \\
\hline 7 & Papar & 1990 & 2015 & 26 \\
\hline 8 & Minggiran & 1992 & 2015 & 24 \\
\hline 9 & Kanigoro & 2002 & 2005 & 4 \\
\hline 10 & Sumber Pucung & 2011 & 2015 & 5 \\
\hline 11 & & &
\end{tabular}

Input utama untuk penelitian ini adalah data debit harian. Data hujan harian dikumulatifkan menjadi hujan bulanan. Sebanyak 15 lokasi stasiun hujan (Tabel 4) yang ada di dalam DAS dipilih untuk mewakili wilayah ke dua Sub-DAS (Brantas Ploso dan Brantas Kertosono). Selanjutnya, data hujan digunakan untuk menentukan kondisi puncak musim kemarau. Puncak musim kemarau digunakan untuk menentukan periode (bulan) kalibrasi.

Gambar 1 juga memperlihatkan histogram hujan rerata bulanan (HRB) dari 11 stasiun hujan terplih. HRB diplot dari rerata hujan bulan Januari sampai dengan Desember dalam bentuk diagram batang untuk menunjukkan bulan paling kering.

Bulan paling kering menunjukkan puncak musim kemarau. Pada Gambar 1, puncak musim kemarau terjadi antara Juli, Agustus dan September (diagram batang yang di beri kotak hitam). Kalibrasi dilakukan pada bulan-bulan kering (Juli, Agustus dan September) dengan asumsi. Pertama, ke 6 metode akan menghitung atau memisahkan komponen aliran dasar dari debit total yang ada di sungai. Proses kalibrasi atau verifikasi dilakukan menggunakan data debit terukur di sungai untuk periode bulan kering (Juli, Agustus, September) dengan asumsi bahwa pada ke tiga bulan tersebut, kompoenen aliran dasar di sungai mendekati $\sim 0$. Asumsi ini tidak mutlak benar adanya, karena pada kenyataan-nya pada ketiga bulan tersebut masih terdapat hujan walaupun sedikit. Kami mengambil asumsi bahwa aliran permukaan yang dihasilkan oleh kejadian hujan pada ke tiga bulan tersebut tidak akan sampai menaikan secara signifikan debit di sungai. Hujan yang jatuh pada ke tiga bulan tersebut relatif kecil bila dibandingkan dengan hujan besar pada bulan yang lain. Hujan kecil hanya cukup untuk membasahi permukaan tanah, tetapi tidak sampai menyebabkan kenaikan hidrograf aliran di sungai. Terlebih lagi pada wilayah yang sangat luas seperti DAS Brantas. Kalibrasi yang paling tepat dilakukan adalah pada saat musim kemarau, dengan asumsi bahwa debit terukur (debit total) yang ada di sungai, sebagian besar adalah berasal dari komponen aliran dasar. Kedua, kompleksitas fenomena hidrologi pada DAS yang relatif luas, sangat sulit untuk dihitung secara akurat, model berfungsi untuk menyederhanakan fenomena tersebut, sehingga dapat dihasilkan perkiraan atau perhitungan yang lebih praktis untuk diterapkan.

Data fisik DAS digunakan untuk mendapatkan gambaran ringkas tentang karakteristik fisik DAS. Data fisik DAS diturunkan dari ASTER GDEM2, peta RBI dan peta tanah dan layer sistem informasi geografis yang ada di Lab. TPKL, FTP, Universitas Jember. Selanjutnya, data DEM (Digital Elevation Model) didownload dari web site Aster GDEM2 (https://asterweb.jpl.nasa.gov/gdem.asp), dipotong se-batas wilayah sub_DAS dan digunakan sebagai input untuk menentukan batas sub-DAS, menentukan jaringan sungai dan parameter morfometri DAS. Data fisik DAS meliputi batas DAS, batas sub-DAS, jaringan sungai, lokasi stasiun hujan, dan stasiun pengukuran debit yang berada di wilayah UPT PSDA Kediri. 
Bentuk ke dua sub-DAS menyerupai tirangle dan cenderung melebar. Luas sub-DAS Kertosono $=6414.2$ $\mathrm{km}^{2}$, luas sub-DAS Ploso $=8844.2 \mathrm{~km}^{2}$. Peruntukan lahan utama yang ada di dalam ke dua Sub-DAS mencakup: lahan persawahan (26.7\%, dan 39\%), hutan (11\% dan 10.85\%), pemukiman (17.4\% dan 5.5\%), kebun (20\% dan 23\%), perladangan (22\% dan $20 \%$ ). Semua angka tersebut adalah dalam prosentase per luas sub-DAS. Lapisan tanah yang ada dari jenis aluvial (21\% dan 26\%), litosol (14\% dan 11\%), andosol (7.1\% dan $7.7 \%$ ), regosol (31.7\% dan 25.3\%), dan mediteran (7.20\% dan 10.87\%) dan latoso (19\% dan 18\%).

\section{Alat dan bahan penelitian}

Hardware dan software yang digunakan dalam penelitian ini mencakup: (1) PC (Personal Computer) digunakan untuk mengolah data, (2) Open office Calc office digunakan untuk mengolah data dan menampilkannya hasil analisis dalam bentuk grafik, dan (3) Modul BFI3+ dari HydroOffice 2015 digunakan untuk memisahkan aliran dasar.

\section{Metode Analisis Data}

\section{Pengolahan Data}

Dalam penelitian ini proses kalibrasi dilakukan menggunakan data debit pada puncak musim kemarau. Puncak musim kemarau (merujuk pada Gambar 1) jatuh pada bulan: Juli, Agustus, September. Pada bulan tersebut hujan tidak turun atau sangat sedikit sekali sehingga diasumsikan aliran air di sungai hanya berasal dari kontribusi aliran dasar (baseflow). Artinya tidak ada atau sedikit sekali aliran air di sungai yang berasal dari aliran permukaan atau air hujan yang mengalir di permukaan tanah secara langsung.

\section{Pembagian Periode Kalibrasi dan Validasi}

Periode rekaman data debit dari 1996 sd 2015, selanjutnya dibagai menjadi dua. Pada 10 tahun pertama (1996 - 2005) digunakan sebagai periode kalibrasi. Pada 10 tahun ke dua (2006 sd 2016) digunakan sebagai periode validasi (Gambar 3).

Kalibrasi dilakukan dengan memasukkan nilai parameter melalui tool calibration pada modul $\mathrm{BFI}^{3+} \mathrm{di}$ atas platform Hydrooffice (Gregor 2012). Metode RDF menggunakan parameter C, k dan/ $\alpha$. Nilai parameter dicobakan setiap tahun, mulai dari 1996. Trial dihentikan jika posisi aliran dasar (debit terhitung - garis yang berwarna merah) dan aliran di sungai (debit total- grafik area biru) saling berhimpit (Gambar 4). Pada saat posisi seperti gambar (4), nilai parameter yang diperoleh kemudian dicatat. Dilanjutkan untuk tahun 1997, 1998 sampai dengan 2005.

Parameter optimal untuk kalibrasi ditentukan dari rerata nilai parameter yang diperoleh setiap tahunnya. Setelah ketemu nilai parameter untuk 1 metode, selanjutnya digunakan metode atau algorithma lain sampai ke enam metode terkalibrasi nilai parameternya.

\section{Validasi}

Validasi adalah proses lanjutan dari proses kalibrasi. Parameter optimal (nilai rerata) hasil kalibrasi tersebut selanjutnya digunakan untuk memisahkan aliran dasar pada periode Kalibrasi (1996 - 2005) dan periode validasi (2006 sd 2015).

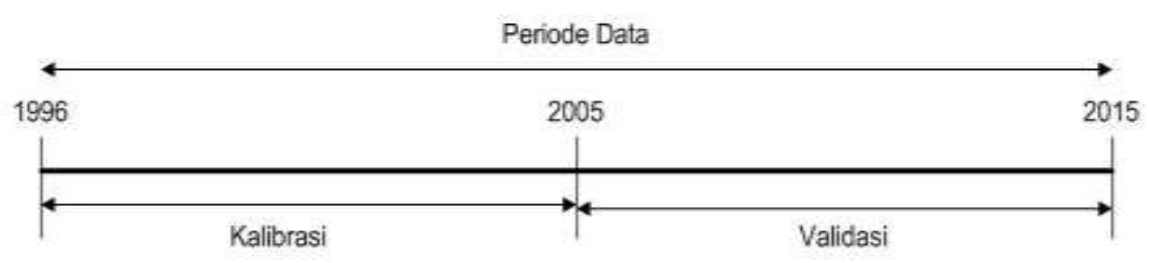

Gambar 3 Pemisahan periode kalibrasi dan validasi. 


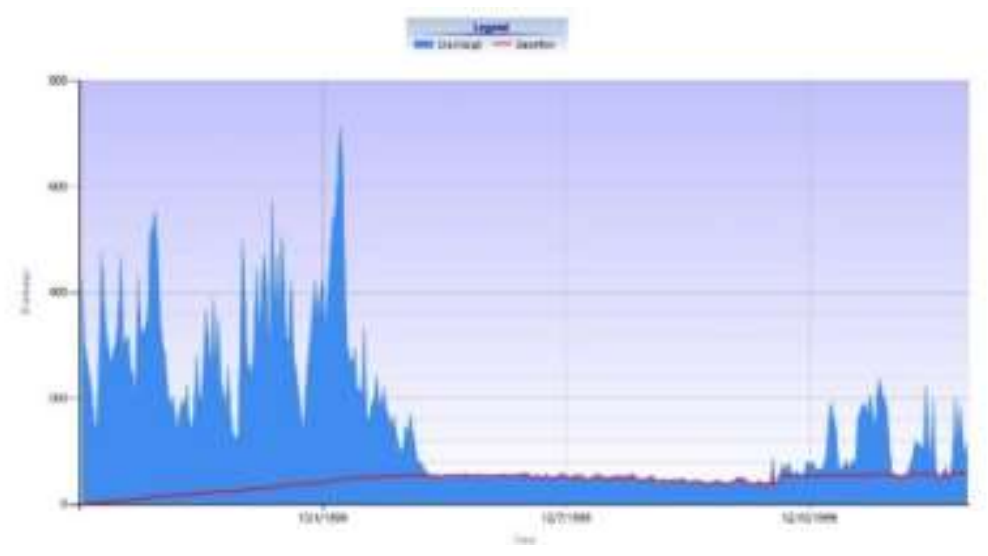

Gambar 4 Visualisasi (metode Lyne Hollick).

\section{Uji Kinerja}

Kinerja dari ke enam (6) algoritma atau model tersebut selanjutnya di evaluasi secara statistik menggunakan RMSE dan koefisien determinasi.

1. Metode selisih akar kuadrat rerata Root Mean Square Error (RMSE) digunakan untuk mengetahui tingkat kesalahan (error) yang dihasilkan pada saat kalibrasi dan validasi. RMSE membandingkan antara debit (base-flow) terhitung dan debit terukur (debit total di sungai) yang diasumsikan sebagai baseflow terukur, untuk menilai kinerja tiap model. Persamaan RMSE :

$$
R M S E=\frac{\sqrt{\sum\left(Q_{m}-Q_{0}\right) 2}}{n}
$$

dimana :

$\mathrm{Q}_{0}=$ debit terukur,

$\mathrm{Q}_{\mathrm{m}}=$ debit terhitung,

$\mathrm{n}=$ jumlah sampel (Indarto, 2012).

Dalam studi ini, data kejadian debit yang digunakan untuk perhitungan RMSE pada periode kalibrasi adalah sejumlah $=(30$ hari $\times 3$ bln $\times 10$ tahun $)=900$ kejadian debit. Dalam hal ini debit terukur diasumsikan sebagian besar terdiri dari komponen aliran dasar. Debit terhitung adalah debit yang dihitung oleh tiap metode pemisahan aliran. Metode pemisahan aliran dinilai lebih baik (lebih tepat) jika dapat memodelkan atau menirukan kondisi debit terukur pada sejumlah 900 kejadian tersebut. Nilai RMSE akan mendekati 0 , untuk metode perhitungan yang berkinerja lebih baik.

2. Koefisien determinasi $\left(\mathrm{r}^{2}\right)$ diperoleh dari scatter-plot antara debit terukur dan terhitung pada periode yang sama. Model yang berkinerja lebih baik akan menghasilkan koefisien determinasi mendekati nilai 1. Hal ini menunjukkan adanya keseuaian antara yang terhitung dan terukur.

\section{Visualisasi}

Visualisasi hasil pemisahan aliran dasar dilakukan menggunakan grafik FDC dan hidrograf hasil pemisahan. Secara visual kinerja persamaan ditampilkan melalui grafik hidrograf dan grafik FDC. 


\section{HASIL DAN PEMBAHASAN}

\section{Hasil Kalibrasi dan Validasi}

\section{Rentang nilai parameter}

Tabel 5 menunjukkan nilai rentang parameter dari 6 metode yang didapatkan dari hasil trial and error pada puncak musim kemarau, setiap tahunnya.

Tabel 5 Rentang nilai parameter.

\begin{tabular}{cccc}
\hline Metode & Parameter & Brantas Kertosono & Brantas Ploso \\
\hline One Parameter & $\mathrm{K}$ & $0.981-0.996$ & $0.993-0.998$ \\
\hline Chapman & $\alpha$ & $0.6-0.92$ & $0.690-0.939$ \\
\hline \multirow{3}{*}{ Ihacres } & $\mathrm{K}$ & $0.79-0.94$ & $0.8-0.9$ \\
\cline { 2 - 4 } & $\mathrm{C}$ & $0.02-0.07$ & $0.02-0.04$ \\
\hline Lyne Hollic & $\alpha$ & $0.71-0.98$ & $0.74-0.87$ \\
\hline \multirow{2}{*}{ TwoParameter } & $\alpha$ & $0.989-0.998$ & $0.994-0.998$ \\
\hline EWMA & $\mathrm{K}$ & $0.950-0.992$ & $0.94-0.99$ \\
\hline & $\mathrm{C}$ & $0.01-0.03$ & $0.01-0.04$ \\
\hline
\end{tabular}

\section{Nilai parameter rerata}

Selanjutnya, dihitung nilai rerata parameter dari trial setiap tahun-nya. Nilai rerata parameter ini selanjutnya digunakan sebagai nilai parameter kalibrasi dan validasi.

Tabel 6 Nilai parameter rerata.

\begin{tabular}{cccc}
\hline Metode & Parameter & Brantas Ploso & Brantas Kertosono \\
\hline One Parameter & $\mathrm{K}$ & 0.996 & 0.992 \\
\hline Chapman & $\alpha$ & 0.833 & 0.813 \\
\hline \multirow{2}{*}{ Ihacres } & $\mathrm{K}$ & 0.854 & 0.856 \\
& $\mathrm{C}$ & 0.034 & 0.044 \\
\hline Lyne Hollic & $\alpha$ & 0.813 & 0.870 \\
\hline \multirow{2}{*}{ TwoParameter } & $\alpha$ & 0.996 & 0.995 \\
\hline EWMA & $\mathrm{K}$ & 0.962 & 0.980 \\
\hline & $\mathrm{C}$ & 0.021 & 0.016 \\
\hline & $\alpha$ & 0.0026 & 0.0028 \\
\hline
\end{tabular}

\section{Uji statistik}

\section{Nilai RMSE}

Nilai RMSE dari periode kalibrasi dan validasi ditampilkan pada Tabel 7 dan 8.

Tabel 7 Nilai RMSE periode kalibrasi.

\begin{tabular}{ccc}
\hline Metode & Brantas Ploso & Brantas Kertosono \\
\hline One Parameter & 1.712 & 0.822 \\
\hline Chapman & 1.629 & 1.072 \\
\hline Ihacres & 2.035 & 1.198 \\
\hline Lyne and Hollick & 0.493 & 0.121 \\
\hline Two Parameter & 1.977 & 1.041 \\
\hline EWMA & 0.556 & 0.127 \\
\hline
\end{tabular}


Tabel 8 Nilai RMSE periode validasi.

\begin{tabular}{ccc}
\hline Metode & Brantas Ploso & Brantas Kertosono \\
\hline One Parameter & 3.144 & 2.389 \\
\hline Chapman & 4.685 & 3.154 \\
\hline Ihacres & 5.890 & 3.537 \\
\hline Lyne and Hollick & 1.211 & 0.392 \\
\hline Two Parameter & 5.606 & 3.154 \\
\hline EWMA & 1.350 & 0.512 \\
\hline
\end{tabular}

Tabel (7) menunjukan metode lyne and hollick dan EWMA menghasilkan nilai RMSE yang kecil dibandingkan dengan metode lainnya. Selanjutnya, pada periode validasi kedua metode tersebut menghasilkan nilai RMSE yang juga cukup kecil (Tabel 8). Oleh karena itu, ke dua metode ini dapat dikatakan memiliki kinerja yang baik untuk memisahkan aliran dasar dari aliran total pada kedua DAS.

\section{Nilai koef. determinasi (R2)}

Nilai $\mathrm{R}^{2}$ dari periode kalibrasi dan validasi disajikan pada tabel 9 dan tabel 10. Kinerja model yang baik dapat dilihat dari nilai $R$-Square yang mendekati $\sim$. Tabel 9 dan Tabel 10 menunjukkan metode lyne and hollick dan EWMA menghasilkan nilai $R$-Square yang cukup tinggi.

\section{Visualisasi}

\section{Flow Duration Curve (FDC)}

Kinerja dari ke enam metode RDF dapat juga dilihat dari grafik KDA (kurva durasi aliran) atau FDC (Indarto 2017). Grafik FDC (gambar 5 dan 6) memplotkan debit besar (debit banjir) di bagian kiri sedangkan debit kecil divisualisasikan di bagian kanan bawah. Grafik pada gambar 5 dan 6 merupakan master FDC dan dibuat dari semua kejadian debit mulai 1996 sd 2015 (selama 20 tahun).

Tabel 9 Nilai koef determinai $\left(\mathrm{R}^{2}\right)$ : kalibrasi

\begin{tabular}{ccc}
\hline Metode & Brantas Ploso & Brantas Kertosono \\
\hline One Parameter & 0.547 & 0.780 \\
\hline Chapman & 0.841 & 0.943 \\
\hline Ihacres & 0.774 & 0.907 \\
\hline Lyne and Hollick & 0.954 & 0.990 \\
\hline Two Parameter & 0.684 & 0.785 \\
\hline EWMA & 0.941 & 0.989 \\
\hline
\end{tabular}

Tabel 10 Nilai koef determinai $\left(\mathrm{R}^{2}\right)$ : Validasi

\begin{tabular}{ccc}
\hline Metode & Brantas Ploso & Brantas Kertosono \\
\hline One Parameter & 0.711 & 0.725 \\
\hline Chapman & 0.800 & 0.966 \\
\hline Ihacres & 0.734 & 0.944 \\
\hline Lyne and Hollick & 0.946 & 0.982 \\
\hline Two Parameter & 0.602 & 0.788 \\
\hline EWMA & 0.934 & 0.970
\end{tabular}




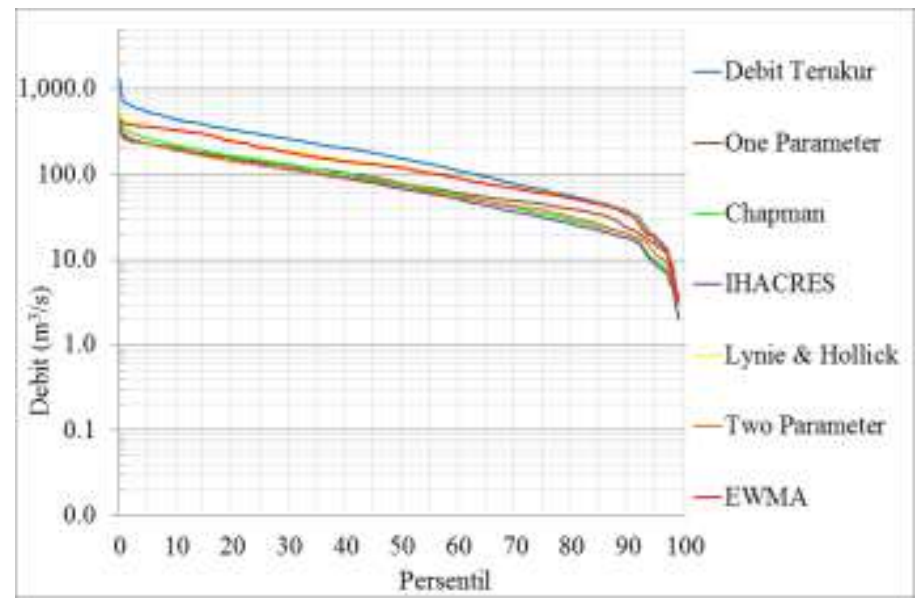

Gambar 5 Visualisasi FDC sub-DAS Brantas Kertosono (full periode 1996 - 2015).

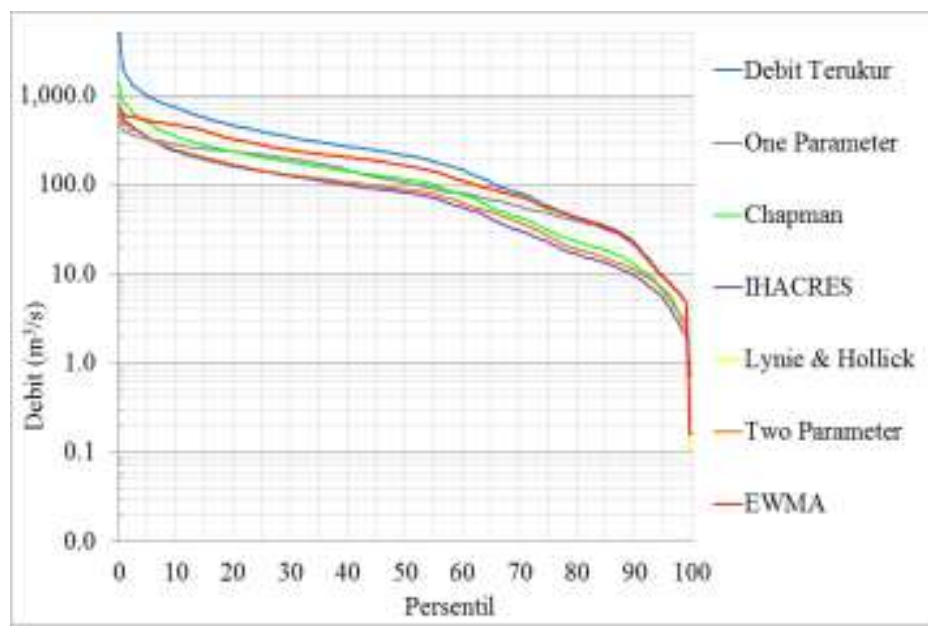

Gambar 6 Visualisasi FDC sub-DAS Brantas Ploso (full periode 1996 - 2015).

Selanjutnya, metode pemisahan yang dapat bekerja dengan baik akan menghasikan grafik yang berimpit antara debit terukur dan debit terhitung pada bagian kanan-bawah. Hal ini menunjukkan kinerja pada musim kmarau, dimana antara debit terhitung oleh tiap metode berimpit dengan debit terukur pada ke tiga bulan kalibrasi tersebut. Sebaliknya, pada periode hujan atau bulan Oktober sampai dengan Mei maka kurva master FDC tidak berimpit dengan kurva FDC hasil perhitungan dari tiap model. Dalam konteks ini, maka metode pemisahan yang baik akan dapat memisahkan komponen baseflow dari debit total-nya. Komponen baseflow digambarkan oleh kurva dari tiap metode pemisahan yang digunakan.

Gambar 5 dan Gambar 6 menunjukkan bahwa metode "lyne and hollick" dan metode "EWMA" memiliki kinerja yang baik pada kedua sub-DAS. Hal ini dikarenakan selisih antara baseflow yang dihasilkan kedua metode tersebut dengan debit terukur sangat kecil dan menghasilkan grafik yang saling berhimpitan dibagian kanan-bawah. Sebalinya, pada bagian kiri atas grafik tidak berimpit, yang menunjukkan bahwa kedua metode dapat memisahkan komponen baseflow dari debit total nya. Pada musim penghujan atau bulan dimana banyak terjadi hujan, grafik FDC didominasi oleh komponen aliran cepat (aliran permukaan) atau quick flow. Komponen quick flow hasil pemisahan dapat digunakan untuk memperkirakan potensi debit yang lebih selama musim penghujan, perkiraan debit banjir atau potensi aliran yang dapat dipanen. 


\section{Visualisasi hidrograf}

\section{a. Zoom untuk Periode 1 Tahun}

Gambar 7 menunjukkan hasil pemisahan baseflow dari 6 metode untuk periode satu tahun pada masingmasing DAS. Gambar 7 dan 8 menunjukkan bahwa nilai debit sungai pada musim kemarau cenderung menurun, karena hujan sangat sedikit atau hampir tidak ada hujan yang terjadi pada musim tersebut, sedangkan pada musim penghujan debit di sungai cenderung meningkat.

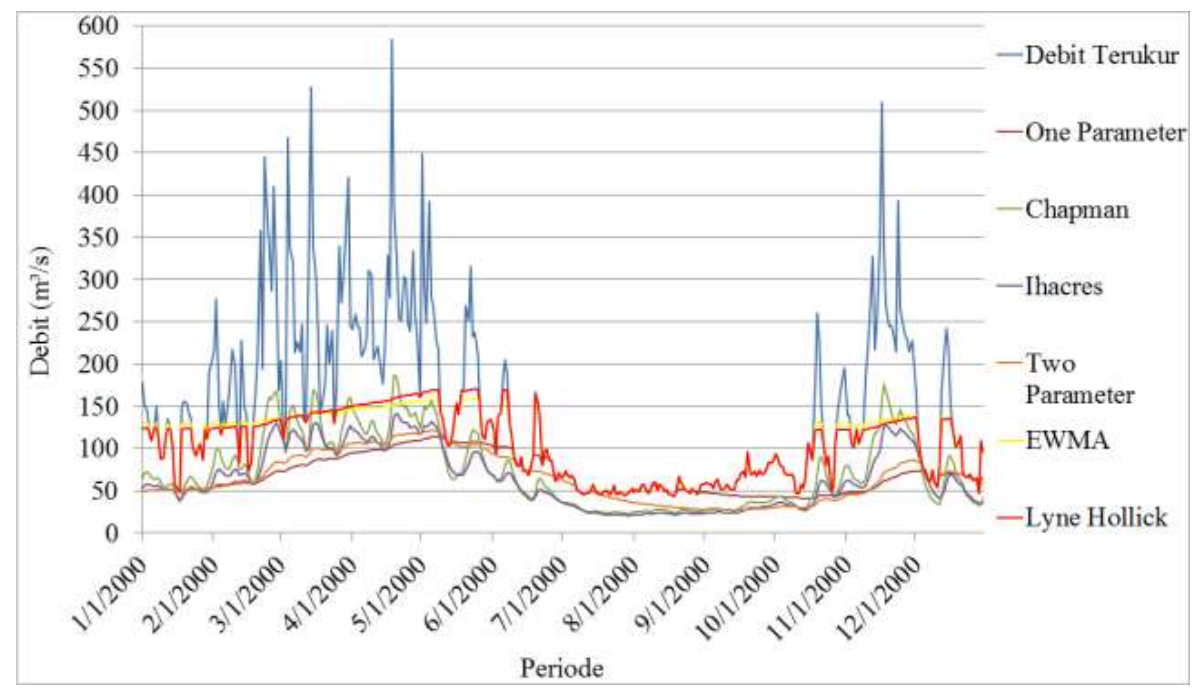

Gambar 7 Hasil pemisahan aliran dasar pada sub-DAS Brantas Kertosono (Zoom mulai 1 Januari- 31 Desember 2000).

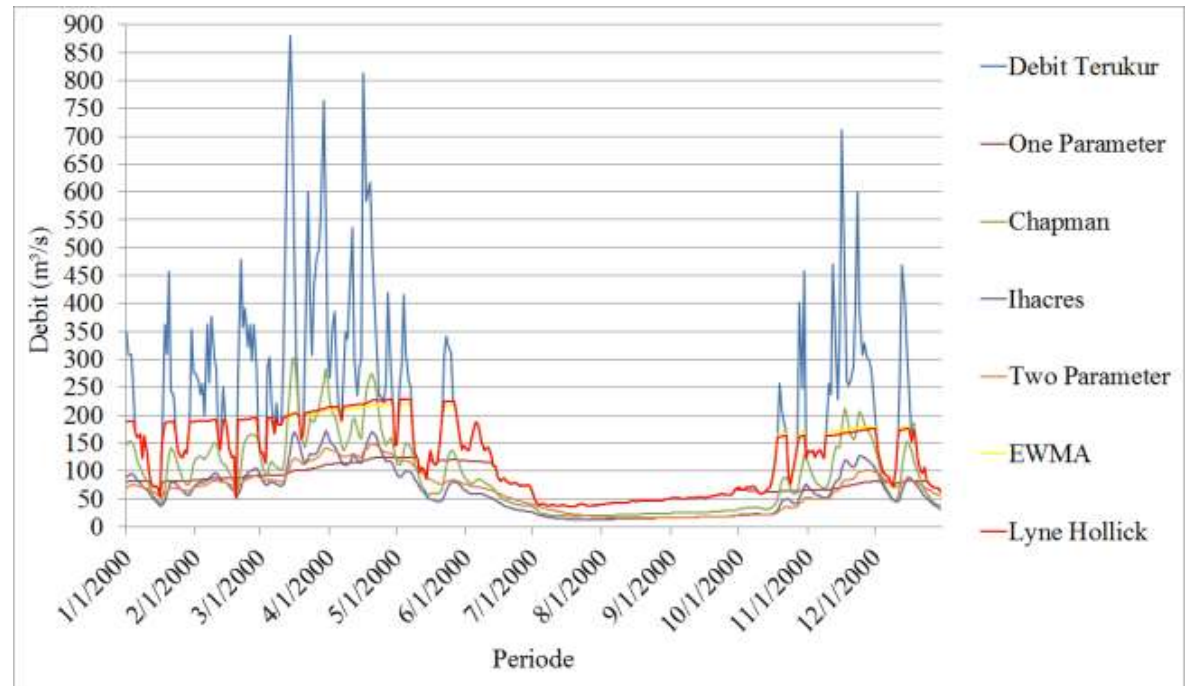

Gambar 8 Hasil pemisahan aliran dasar pada sub-DAS Brantas Ploso (Zoom mulai 1 Januari- 31 Desember 2000).

Puncak hidrograf di atas garis merah, menunjukkan bagian hidrograf yang merupakan komponen aliran cepat (quick flow) atau aliran permukaan. Debit di atas garis merah inilah yang dapat dipanen untuk ditampung atau sebaliknya berpotensi menghasilkan banjir jika terlalu besar. Sementara, nilai debit di bawah grafik merah menunjukan komponen aliran dasar. 


\section{b. Periode kering Juli-September}

Gambar 9 dan 10 menunjukkan hasil pemisahan baseflow dari 6 metode untuk periode musim kering.

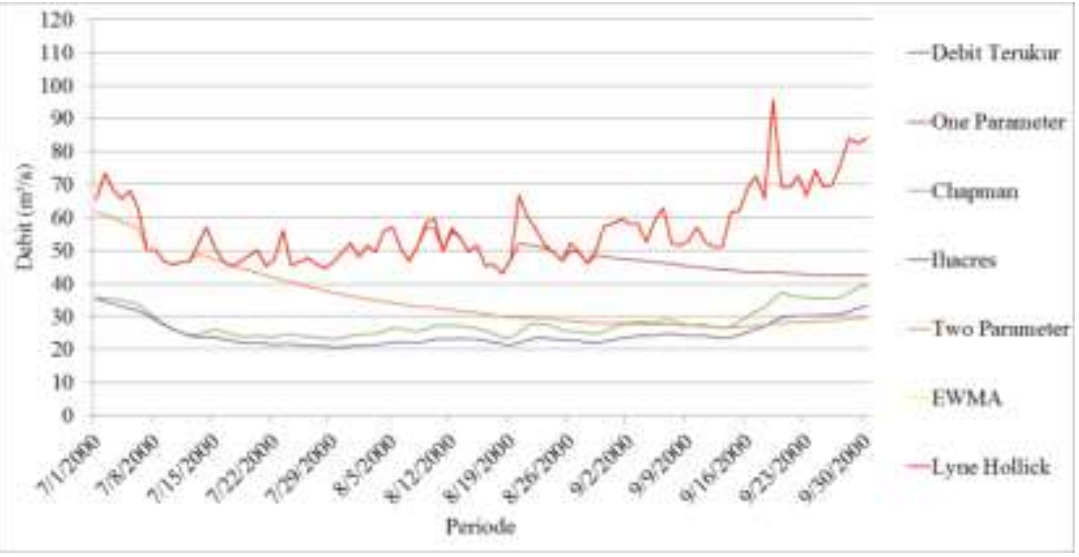

Gambar 9 Hasil pemisahan aliran dasar pada sub-DAS Brantas Kertosono

(Zoom: 1 Juli - 30 September 2000).

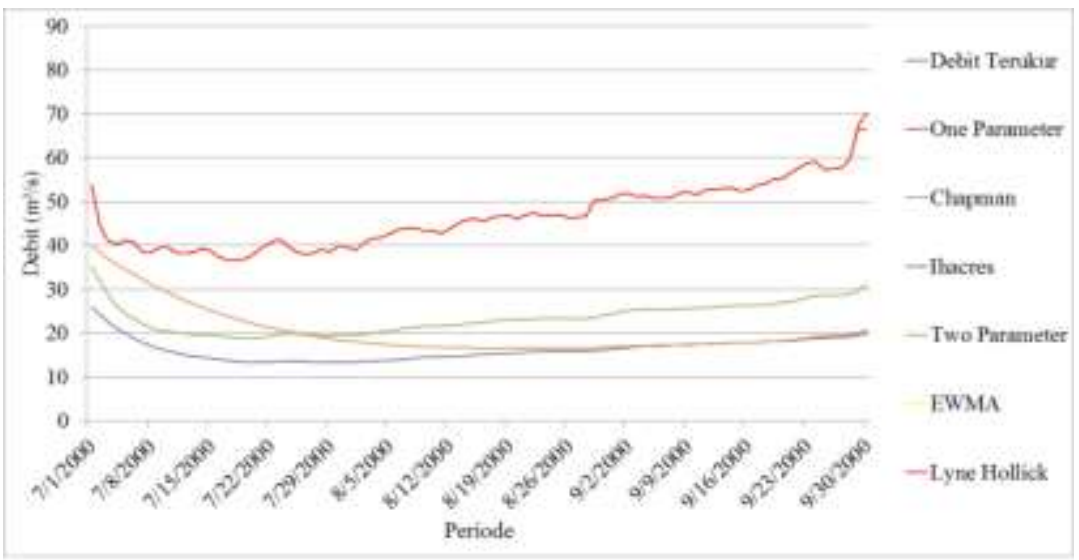

Gambar 10. Hasil pemisahan aliran dasar pada sub-DAS Brantas Ploso (Zoom 1 Juli - 30 September 2000).

Gambar 9 dan 10 memperlihatkan bahwa metode Lyne and hollick dan EWMA memiliki kinerja yang lebih baik dalam pemisahan aliran dasar dibandingkan dengan metode lainnya. Metode yang memiliki kinerja yang baik dalam pemisahan aliran dasar akan menghasilkan baseflow yang hampir sama dengan debit terukur saat musim kemarau karena saat itu masih ada hujan. Hal ini dapat di ketahui dari grafik antara debit terukur dengan grafik lyne and hollick dan EWMA yang saling berhimpitan pada musim kemarau.

\section{Baseflow Index (BFI)}

BFI merupakan perbandingan antara debit aliran dasar dengan debit total aliran sungai (debit aliran dasar terhitung/debit total). Nilai baseflow index dari enam metode RDF tahun 1996 - 2015 disajikan pada tabel 11. Tabel 11 meringkas hasil perhitungan baseflow sepanjang periode percobaan (20 tahun $\mathrm{x} 360$ hari/tahun $)=$ 7200 ulangan (kejadian debit). Nilai BFI rerata adalah nilai rerata sepanjang periode tersebut (termasuk musim kemarau dan musim penghujan). Pada musim penghujan kontribusi aliran dari baseflow rendah, bahkan dapat mendekati NOL (nilai minimum). Hal ini dapat terjadi misalnya pada puncak musim penghujan. Beberapa kejadian hujan lebat dapat terjadi berturutan selama beberapa hari. Kondisi lapisan tanah di dalam DAS menjadi jenuh, sehingga secara umum pada DAS tersebut infiltrasi mendekati Nol, sebagian besar hujan dikonversi menjadi aliran permukaan, sehingga nilai BFI $=$ (baseflow/total flow $) \sim 0$.

Sebaliknya, Nilai BFI juga dapat mencapai maksimum (mendekati $\sim$ ) ketika puncak musim kemarau. Pada wilayah DAS Brantas puncak musim kemarau terjadi pada tiga bulan (Juli, agustus, september), 
kontribusi aliran bawah tanah (base flow) pada musim kemarau panjang menjadi maksimal, karena aliran permukaan (run Off) tidak terjadi atau mendekati NOL. Nilai BFI = (debit base flow/debit total $) \sim 1$. Karena untuk beberapa kejadian musim kemarau nilai aliran permukaan ( + aliran permukaan $=$ baseflow +0 .

Ketersediaan air sungai pada musim kemarau dipengaruhi oleh besarnya nilai baseflow index. Tallaksen dan Van Lannen (2004) mengatakan bahwa nilai baseflow index yang berkisar 0.9 menunjukan DAS yang permeable. Nilai baseflow index yang tinggi menggambarkan DAS yang memiliki jenis aliran relatif stabil dan DAS tersebut mampu memberikan suplai air ke sungai meskipun pada musim kemarau. Nilai baseflow index yang rendah ( antara 0,15 sampai 0,2) menunjukkan DAS yang impermeable dengan debit aliran yang cepat hilang.

Tabel 11 menunjukkan bahwa enam metode RDF menghasilkan nilai BFI yang bervariasi. Metode Lyne and Hollick dan metode EWMA menghasilkan nilai BFI yang tinggi pada setiap sub-DAS. Nilai BFI rerata dari metode Lyne and Hollick $=0.85$ dan metode EWMA $=0.84$ untuk sub-DAS Brantas kertosono. Sedangkan nilai BFI pada sub-DAS brantas ploso untuk metode Lyne and Hollick dan EWMA $=0.84$. Nilai BFI rerata yang tinggi menunjukkan kontribusi aliran dasar cukup tinggi, memungkinkan sungai dapat mempertahankan aliran dalam jangka panjang (sehingga tetap ada air pada musim kemarau).

Tabel 11 Hasil perhitungn nilai BFI.

\begin{tabular}{ccccccc}
\hline \multirow{2}{*}{ Metode } & \multicolumn{3}{c}{ Brantas Ploso } & \multicolumn{3}{c}{ Kertosono } \\
\cline { 2 - 7 } & Maks & Min & Rerata & Maks & Min & Rerata \\
\hline One Parameter & 1.00 & 0.00 & 0.62 & 1.00 & 0.01 & 0.70 \\
\hline Chapman & 1.00 & 0.08 & 0.52 & 1.00 & 0.09 & 0.56 \\
\hline Ihacres & 1.00 & 0.03 & 0.47 & 1.00 & 0.04 & 0.41 \\
\hline Lyne Hollick & 1.00 & 0.00 & 0.85 & 1.00 & 0.00 & 0.84 \\
\hline Two Parameter & 1.00 & 0.02 & 0.54 & 1.00 & 0.02 & 0.47 \\
\hline EWMA & 1.00 & 0.00 & 0.84 & 1.00 & 0.00 & 0.84 \\
\hline
\end{tabular}

\section{SIMPULAN}

Hasil penelitian menunjukan bahwa pada prinsipnya semua metode dapat digunakan pada wilayah subDAS Brantas. Selanjutnya, berdasarkan kriteria pada uji statistik (RMSE, koefisien determinasi atau $\mathrm{R}^{2}$ ) dan visualisasi (melalui kurva FDC dan hydrograf aliran) metode Lyne \& Hollick dan metode EWMA menunjukkan kinerja lebih baik dari ke empat metode lainnya. Nilai parameter alfa $(\alpha)$ yang diperoleh untuk sub-DAS Brantas Kertosono yaitu $\alpha_{\mathrm{ly}}=0.995$ (untuk metode Lyne-Hollick) dan $\alpha_{\mathrm{ew}}=0.003$ (untuk metode EWMA). Pada sub-DAS Brantas Ploso nilai $\alpha_{\mathrm{ly}}=0.996$ dan $\alpha_{\mathrm{ew}}=0.003$. Nilai BFI rerata selama periode 1996 sd 2015 yang terhitung oleh ke enam metode berkisar antara 0.41 sd 0.84 .

\section{UCAPAN TERIMA KASIH}

Penelitian ini merupakan bagian dari skim Hibah Kompetensi a.n Indarto yang didanai oleh DRPM selama periode 2016 - 2017. Ucapan terima kasih disampaikan kepada DRPM kementrian Ristek Dikti, LP2M UNEJ, dan kantor UPT PSDA di Kediri. Terima kasih juga disampaikan kepada semua mahasiswa yang telah bekerja keras dan belajar untuk mendalami pemodelan hidrologi melalui skripsi a.l: Nur defitri Herlinda, mujiono hardiansyah, Isnani Didik, Desi Ratnasari, Natalia Puspita Sari, dan semua pihak yang telah membantu selama proses penelitian berlangsung. 


\section{DAFTAR PUSTAKA}

Boughton WC. 1993. A hydrograph-based model for estimating water yield of ungauged catchments, Institute of Engineers Australia National Conference. Publ. 93(14): 317-324.

Brodie R and Hostetler S. 2007. An overview of tools for assessing groundwater-surface water connectivity. Canberra: Bureau of Rural Sciences.

Chapman TG and Maxwell AI. 1996. Baseflow separation - comparison of numerical methods with tracer experiments. Institute Engineers Australia National Conference. Publ. 96(5): 539-545.

Chapman TG. 1991. Comment on evaluation of automated techniques for base flow and recession analyses, by RJ Nathan and TA McMahon. Water Resources Research. 27(7), 1783-1784.

Chapman TG. 1999. A Comparison Of Algorithms For Streamflow Recession And Baseflow Separation Hydrological Processes. Australia: Institute of Engineers Australia.

Eckhardt K. 2008. A comparison of base flow indices, which were calculated with seven different base flow separation methods. J. Hydrol. 352: 168-173.

Furey PR. 2003. Tests of two physically based filters for base flow separation. Water Resources Research 39(10). doi:10.1029/2002WR001621.

Gonzales AL, Nonner J, Heijkers J, and Uhlenbrook S. 2009. Comparison of different base flow separation methods in a lowland Catchment. Hydrol. Earth Syst. Sci. 13, 2055-2068.

Gregor M. 2010. Hydrooffice User Manual version. 2012. http://hydrooffice.org.

Gregor M. 2012. Hydrooffice User Manual version. 2012. http://hydrooffice.org.

Gregor M. 2015. Hydrooffice User Manual version. 2015. http://hydrooffice.org.

Indarto I, Elida N, and Sri W. 2015. Preliminary Study on Baseflow Separation at Watersheds in East Java Regions. Agriculture and Agricultural Science Procedia, 9:538-550. DOI: 10.1016/j.aaspro.2016.02.174.

Indarto, Suhardjo W, Agung PS. 2013. Physical properties and flow Duration Curves of 15 Watresheds in East Java. Agritech. 33(4).

Indarto. 2010. Hidrologi - Dasar Teori Dan Contoh Aplikasi Model Hidrologi ( ISBN: 978-979-010-579-9). PT Bumi Aksara.

Indarto. 2016. Hidrologi - Metode Analisis dan tool untuk interpretasi Hidrograf Aliran Sungai. PT Bumi Aksara.

Institute of Hydrology. 1980. Low flow studies. Res. Rep. 1. Institute of Hydrology. UK:Wallingford.

Jakeman AJ dan Hornberger GM. 1993. How Much Complexity Is Warranted in a Rainfall-Runoff Model? Water Resources Research. 29(8): 2637-2649.

Linsley RK, Kohler MA, Paulhus JLH, Wallace JS. 1958. Hydrology for engineers. New York: McGraw Hill.

Lyne V and Hollick M. 1979. Stochastic time-variable rainfall-runoff modelling. Institute of Engineers Australia National Conference. Publ. 79(10): 89-93.

Marsh N. 2004. Time Series Analysis Module: River Analysis Package, Cooperative Research Centre for Catchment Hydrology. Melbourne Australia: Monash University.

Mau DP, and Winter TC. 1997. Estimating ground-water recharge from streamflow hydrographs for a small mountain watershed in a temperate humid climate. New Hampshire, USA. Ground Water. 35(2): 291304.

Mulla DI dan Addiscott TM. 1999. Validation Approaches For Field-, Basin-, And Regional Scale Water Quality Models. In: Assessment Of Non-Point Source Pollution In The Vadose Zone. Geophysical Monograph 108. Washington DC: Amirican Geophysical Union.

Murphy R, Graszkiewicz, Hill P, Neal B, Nathan R, Ladson T. 2009. Australian rainfall and runoff revison. Project 7: baseflow for catchment simulation. AR\&R Report Number, P7/S1/004, ISBN: 978-085825- 
9218, Engineers Australia, Engineering House 11, National Circuit, Barton ACT 2600.

Nathan RJ and McMahon TA. 1990b. Estimating low flow characteristics in ungauged catchments. Water Res. Manage. 6: 85-100.

Nathan RJ, and McMahon TA. 1990a. Evaluation of automated techniques for baseflow and recession analysis. Water Resources Publications. 26(7):1465-1473.

Pettyjohn WA and Henning R. 1979. Preliminary estimate of ground-water recharge rates, related streamflow and water quality in Ohio, Ohio State University Water Resources Centre Project Completion Report No 552.

Priyanto ID. 2015. Studi Baseflow Menggunakan Perbandingan Metode Grafis Dan Metode Rdf (Recursive Digital Filter) (Studi Kasus Di Wilayah Upt Psda Pasuruan). URI: http://repository.unej.ac.id/123456789/64992.

Purnamasaria I, H Pawitan, F Renggono. 2017. Analysis of Meteorological Drought Propagation to Hydrological Drought through Larona Watershade. Jurnal Pengelolaan Sumberdaya Alam dan Lingkungan. 7(2): 163-171.

Puspitasari ND. 2015. Analisis Baseflow Menggunakan Metode Grafis Dan Metode Rdf (Recursive Digital Filter) (Studi Kasus Di Wilayah Upt Psda Bondowoso). URI: http://repository.unej.ac.id/123456789/65381. Date: 2015-12-01.

Ratnasari D. 2015. Study baseflow menggunakan perbandingan 6 metode RDF (Recursive Digital Filter) (Studi Kasus di DAS Wilayah UPT PSDA Bondowoso. URI: http://repository.unej.ac.id/123456789/72841. Date: 2016-01-28.

Smakhtin VU. 2001a. Estimating continuous monthly baseflow time series and their possible applications in the context of the ecological reserve. Water SA. 27(2): 213-217.

Smakhtin VU. 2001b. Low flow hydrology: a review. J Hydrology. 240: 147-186.

Tallaksen LM, Vvan Lanen HAJ. van eds. 2004. Hydrological Drought - Processes and Estimation Methods for Streamflow and Groundwater. Developments in Water Science, 48. Amsterdam, Elsevier Science B.V, ISBN 0-444-51688-3, pp. 579.

Tallaksen LM. 1995. A review of baseflow recession analysis. Journal of Hydrology. 165: 349-370.

Tularam GA dan Ilahee M. 2008. Exponential Smoothing Method of Base Flow Separation And Its Impact on Continuous Loss Estimates. American Journal of Environmental Sciences. 4(2): 136-138.

Yetti E, D Soedharma, S Haryadi. 2017. Evaluation of Rivers Water Quality at Malang Upper Brantas River Basin Area in Relation to Land Use System and Its Surroundings People Activity. Jurnal Pengelolaan Sumberdaya Alam dan Lingkungan. 7(2): 98-106.

Zumaa DS, Murtilaksono K, Suharnoto Y. 2017. Analysis of Rainfall and Discharge with SWAT Model Using the Moving Average Method in Ciliwung Hulu Watershed. Jurnal Pengelolaan Sumberdaya Alam dan Lingkungan. 7(2): 98-106. 